\title{
Traditional Methods and Techniques Used for Earthen Buildings
}

\author{
Tudorel Șeitan and Ana Maria Grămescu
}

\begin{abstract}
In all arid regions of the globe, but also in those with temperate climates, earth was the predominant building material. In modern times, at least a third of the planet's population lives in earthen houses. The task of providing the necessary construction materials is proving to be quite difficult, even in highly developed countries. Moreover, the irrational exploitation of resources and the elevated levels of production and consumption is not only a waste, but also a source of environmental pollution. In this context, we can talk about the earth as a naturally abundant material that could be the most important resource for construction. It can be both a low-cost building material, but also a material that can meet the current requirements for efficient, low-carbon emission and low-carbon footprint housing.
\end{abstract}

Keywords - adobe, cob, earthen buildings, traditional methods and techniques

\section{INTRODUCTION}

People often value low-energy consumption and affordability when building their homes, with a focus on a healthy, balanced indoor climate. Earthen constructions are an environmentally friendly and less expensive alternative to constructions made of concrete or ceramic blocks and with a substantially lower carbon dioxide footprint. In our country, the lack of design codes, studies and tests can deter potential users. In general, architects and structural engineers are avoiding recommending this type of material, even for minor or unimportant constructions.

In modern times, some states have adopted this material and developed regulations governing its use. In the US for example, regulations ask for minimum compression strength of $2 \mathrm{~N} / \mathrm{mm}^{2}$ for a material to be used in load bearing elements. If these conditions are met and the structure is designed in such a way as to provide sufficient resistance to dynamic loads then the walls become load bearing.

\section{HISTORY OF EARTH CONSTRUCTIONS}

The technique of building with earth dates back more than 9000 years. In Turkistan, houses between 8,000 and 10,000 years old have been discovered, and in Assyria, earthen foundations about 7,000 years old. The land was used both in construction for housing but also for places of worship. Figure 1 shows the arches of the temple complex of Ramses II from Egypt, made of earthen bricks. 


\section{sciendo}

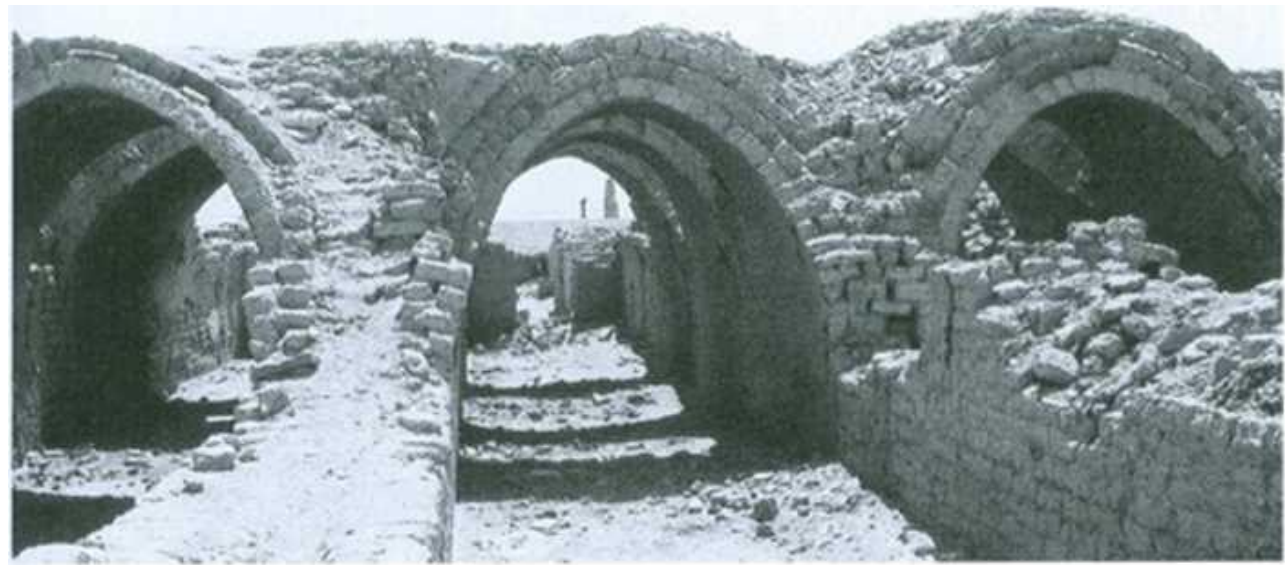

Fig. 1. Arches of the temple complex of Ramses II in El Gouna, Egipt [1]

In Figure 2 the city of Bam in Iran can be observed, which contains old buildings of approx. 2500 years. The fortress is the largest adobe brick structure in the world and it is included among the UNESCO World Heritage Sites. Its importance was greatest between the 7th and 11th centuries as a trade center located at the crossroad of the "Silk Road" and other trade routes.

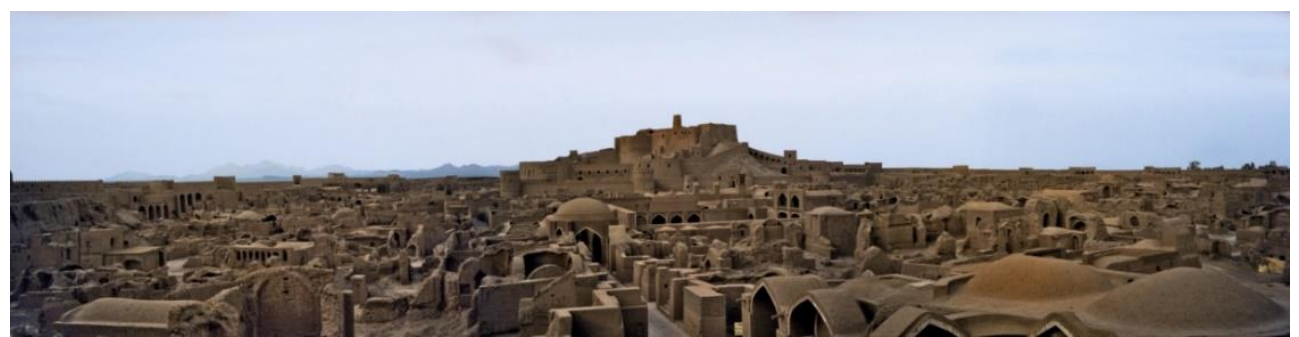

Fig. 2. Bam (Arg-é Bam) Citadel in the province of Kerman, Iran [6]

The core of the Great Wall of China is made of rammed earth and later the stone cladding was added. The nucleus of the Pyramid of the Sun in Teotihuacan, Mexico, built between 300 and $900 \mathrm{AD}$. contains about 2 million tons of rammed earth.

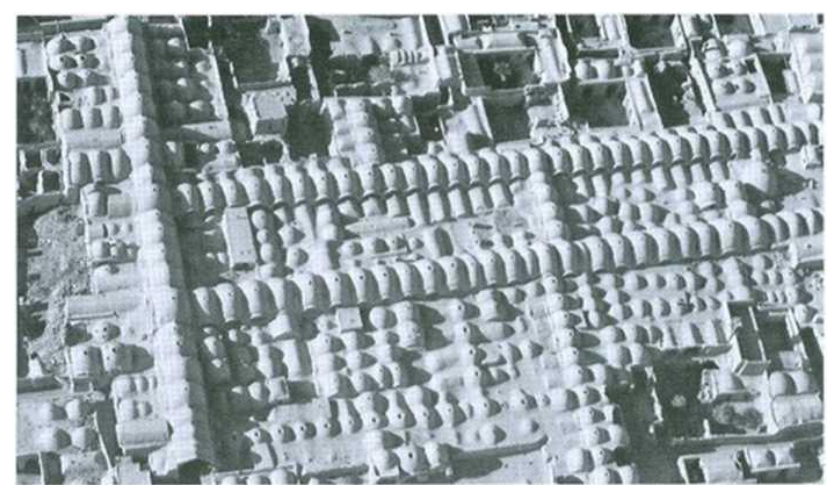

Fig. 3. Cartierul bazar din Sirjan, Iran [1] 


\section{sciendo}

100 Ovidius University Annals Series: Civil Engineering, Year 23, 2021

In arid areas of the world, wood for construction is hard to come by, but the locals found a workaround and developed a technique in which the buildings roofs were made of arches or vaults of adobe bricks without the use of any formwork. Figure 3 illustrates this technique in the bazaar district of Sirjan, Iran.

Other examples are the southern regions of North America, Mexico, Central America, and South America, where the techniques of earth construction were known to all preColumbian cultures. These traditions were preserved until the present day, Figure 4 presenting a 250-year-old earthen construction in Sao Paulo, Brazil.

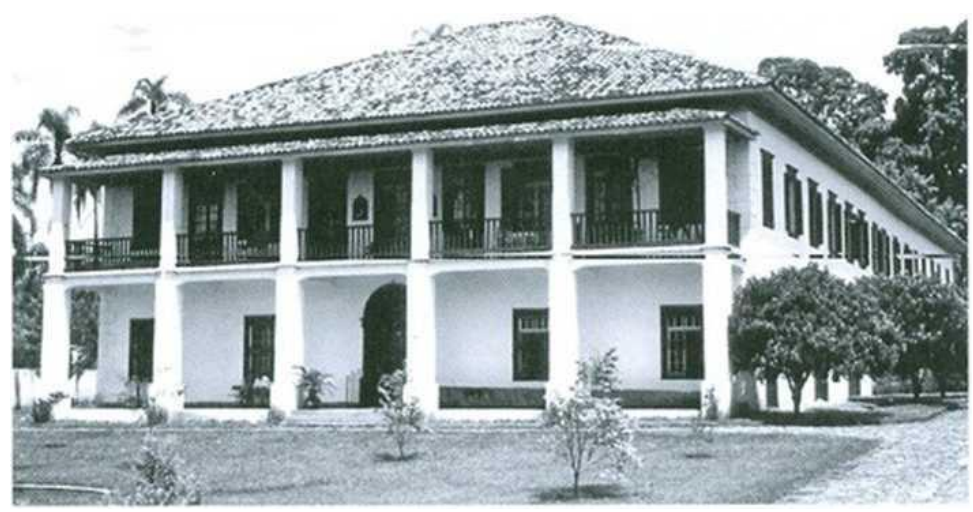

Fig. 4. Rammed earth building in Sao Paulo, Brazil [1]

\section{CHARACTERISTICS, ADVANTAGES, DISADVANTAGES OF USING EARTH AS A BUILDING MATERIAL}

Earth used for the constructions is composed of clay, dust and sand, and sometimes it can also contain gravel. The percentage of clay in the soil has a direct influence on the behavior of the resulting element or brick. Like cement in concrete, it has the role of binding the other larger constituent particles.

Disadvantages include the lack of design codes for earthworks in many parts of the world, but also the fact that it is not a standardized, uniform or homogeneous material. Its particle size differs depending on where it is obtained from. Also, during curing, cracks and contractions may appear, and due to the fact that earth made elements do not have a good water resistance, this poses a significant risk. Water infiltrated by capillarity and subjected to freeze-thaw cycles lead to the degradation of the earth made element.

As advantages, earthen walls have the ability of balancing the temperature and humidity inside. Due to its high density, an earth wall will begin to accumulate heat slowly during the day and radiate that heat over night, essentially balancing the temperatures over a 24 hour cycle. It is reusable, which makes it a very environmentally friendly material and can help save resources.

\section{BUILDING WITH ADOBE BRICKS}

The method of building with adobe bricks has been used successfully in all regions of the globe and it is one of the most common construction techniques. The mixture of earth and straw is poured into molds and allowed to cure in direct sunlight. 


\section{sciendo}

Ovidius University Annals Series: Civil Engineering, Year 23, $2021 \quad 10$

A lower straw content leads to a higher specific weight of the bricks, with the added benefit of balancing the indoor climate. A higher straw content leads to a lower density, higher porosity of the material, which lead to better thermal insulation properties.

After curing, the resulting bricks gain strength and can be used to make walls by stacking bricks on top of each other with a binding mortar made of earth. The walls are built and plastered with mortar made of the same mixture. Traditionally, the foundations are made of stone and earth.

The ceilings are made of wood, planks or straw and earth and built over the walls, and the roofs have a wooden frame with ceramic tiling and straw or reed bales.

In Romania, adobe bricks are called chirpici, a word derived from the Turkish language. (Kerpiç - adobe brick)

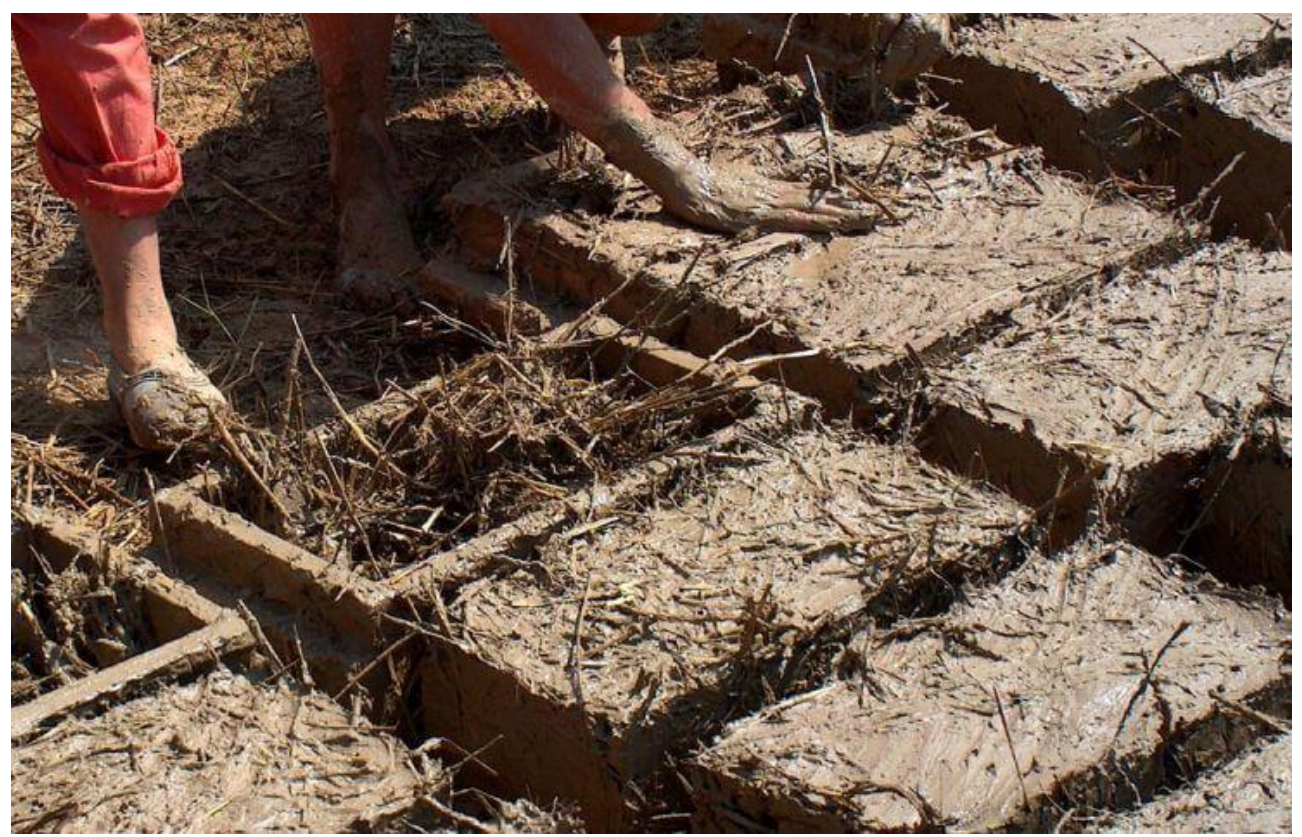

Fig. 5. Traditional Romanian adobe brick (chirpici) [6]

\section{BUILDING WITH COB}

This method involves making a mixture of earth and straw which is then formed by hand into spherical lumps and placed successively on top of each other. Building with these spheres is done while the mixture is still in the wet state and use of mortar for binding is no longer necessary. In the process of positioning the lumps of earth, they are lightly pressed and actions are taken so that the surfaces that come into contact are not perfectly smooth to improve the adhesion between the layers.

After the walls are built, a plaster of the same mixture is applied, with an aesthetic role, but also as a protection against water infiltrations.

As in the case of building with adobe bricks, the ceilings are made of wood and earth, and the roofs are cladded with ceramic or reed.

In some regions of Romania, these spherical pieces of earth are called ceamur, a word also borrowed from the Turkish language. (çamur - mud) 


\section{sciendo}

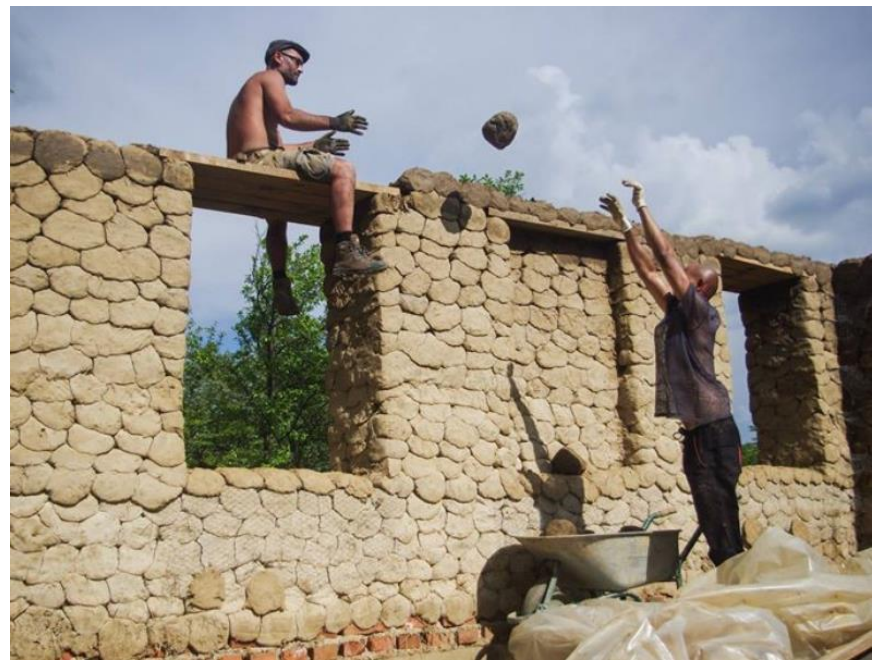

Fig. 6. Wall made with cob [2]

\section{DIRECT MODELING TECHNIQUE}

The simplest and most primitive method is that of direct modeling. Due to the fact that the wet soil mixture can be easily modeled by hand, this method is widely used in Africa and Asia. The mixture is used directly, without formwork, supports or other intermediate products.

In this method, no mortar is used, and the wet clay is applied by throwing, pressing or compacting with a beater. The walls are made in stages of about $60-80 \mathrm{~cm}$ high. For finishing, a plaster is applied made of the same mixture as the wall. The ceilings and roofs can be made of wood or earth, and the roofs can be cladded with ceramic tiles.

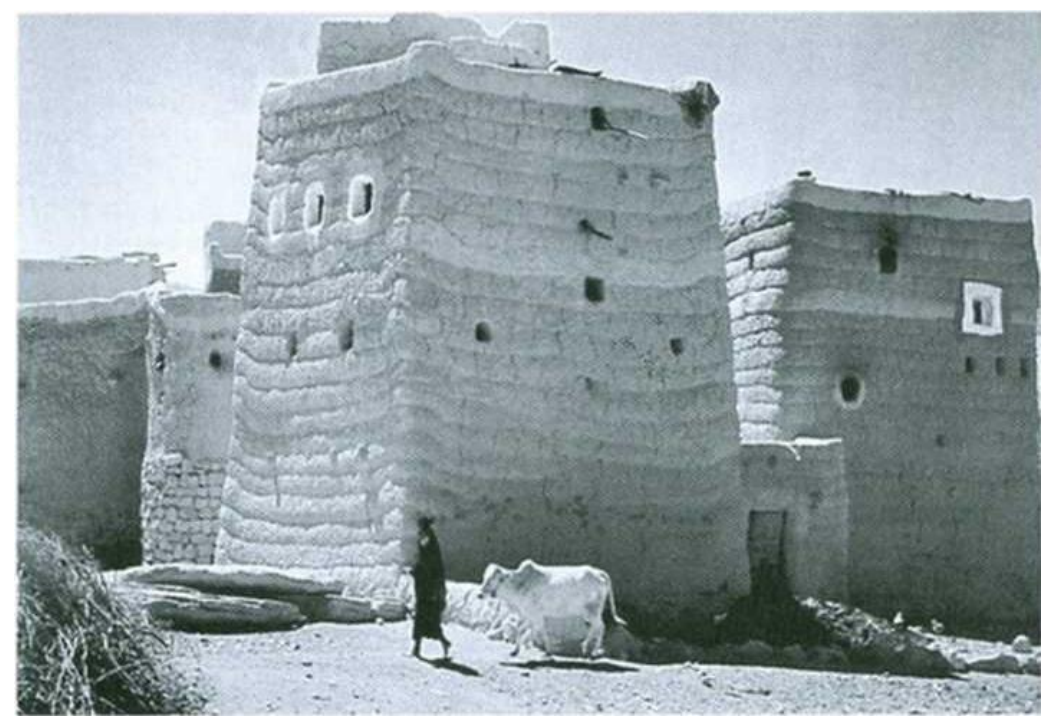

Fig. 7. House made with the direct modeling technique, Yemen [1] 


\section{COBWEB TECHNIQUE}

Traditionally, clay has been used to fill gaps in houses made of horizontally arranged logs. In Europe, the construction of the cobweb walls was preceded by making a wooden frame, over which a net of slats or branches was placed. After that, the wet, malleable earth mixture was thrown or pressed.

The technique of throwing earth is also quite old and it is considered to have been used before rammed earth or adobe blocks. The finishing is done with a plaster of earth, and the floors, ceilings and roof are made of wood.

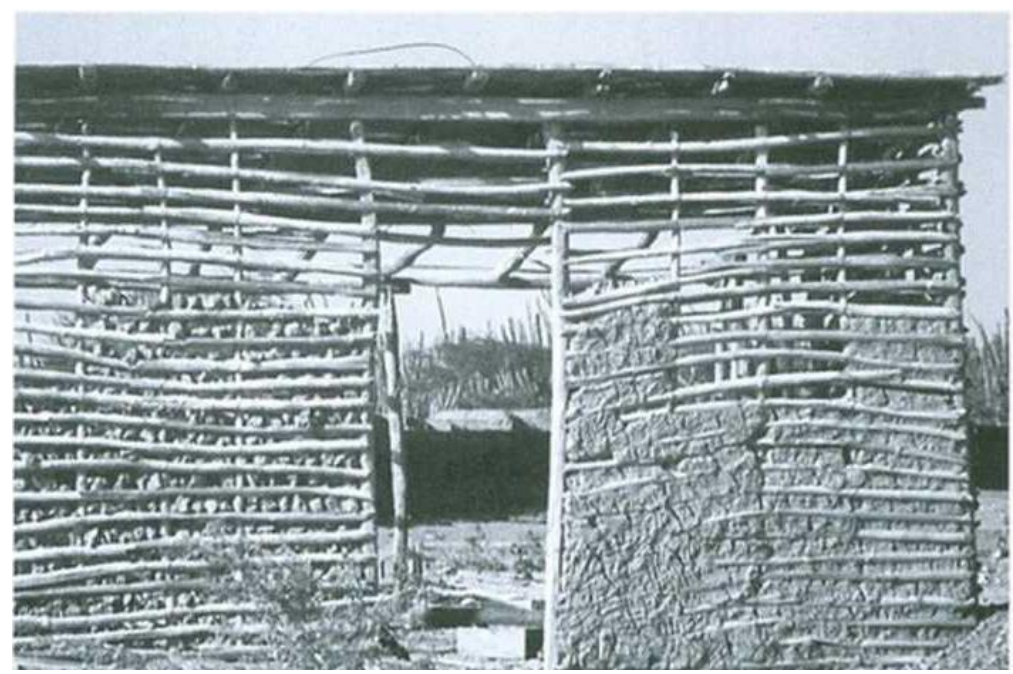

Fig. 8. Traditional cobweb made with branches, Venezuela [1]

\section{RAMMED EARTH}

One of the most common techniques is that of rammed earth, used in structures dating back several thousand years. Traditionally, a mixture of clay soil and dry, chopped straw is used. The principle of this method is to pour the wet soil into formwork and then compact by ramming. The thickness of the layers varies between 15 and $25 \mathrm{~cm}$.

It is also the current method in developed countries such as the USA or New Zealand. In these countries, design codes have been developed, and the demand and supply of houses made with this technique have been increasing steadily for more than 20 years. Construction companies which work with this type of material exclusively, over time, have developed recipes and technologies that have been approved and put into practice. It is a fairly easy transition from working with reinforced concrete in terms of labor and formwork used, and the mechanization of the ramming process has reduced the need for manual labor.

The wall in figure 9 is made of rammed earth, stabilized with cement. In general, about $10 \%$ cement is used for stabilization, but this percentage may vary depending on the nature of the soil. Straw is no longer used. The resulting walls are load bearing, and reinforced concrete elements can be integrated for a better structural behavior. The resulting wall has a smooth, flat surface with a good resistance to weather. Plaster is no longer required and the appearance is pleasing from an aesthetic point of view. The flatness of the surfaces is ensured by the quality of the formwork. 


\section{sciendo}

104 Ovidius University Annals Series: Civil Engineering, Year 23, 2021

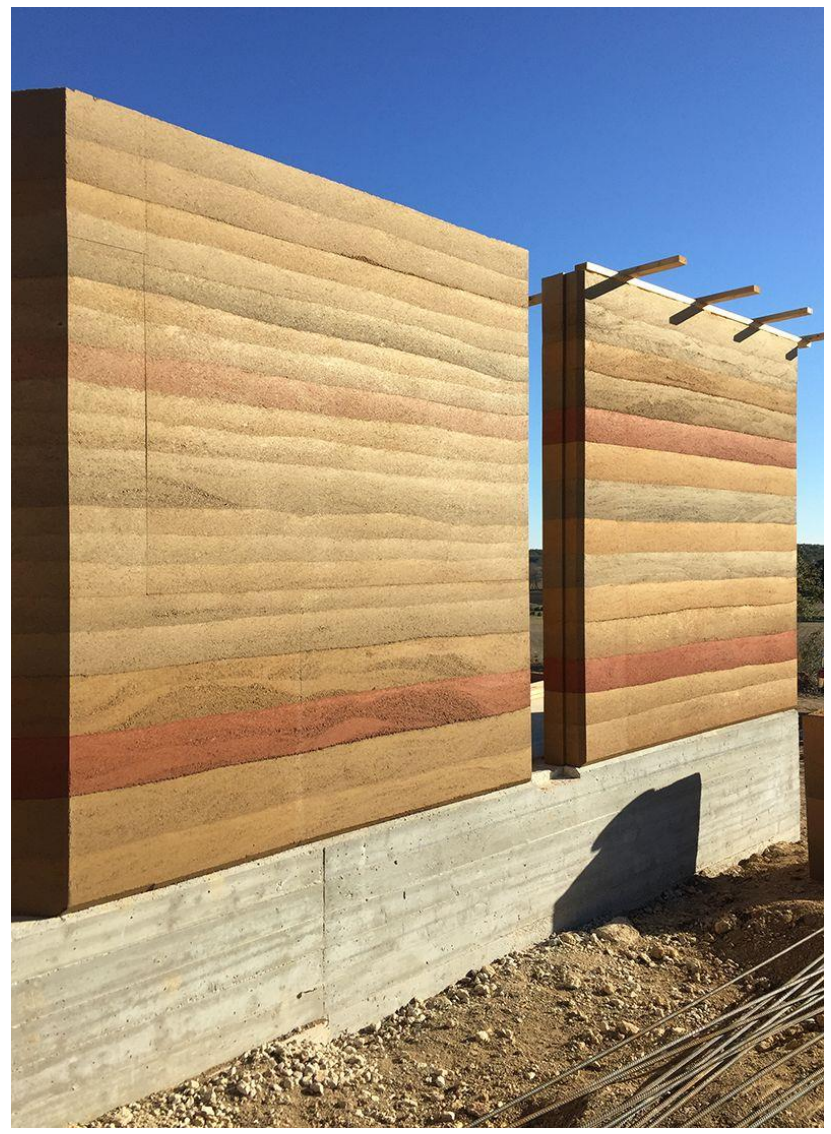

Fig. 9. Rammed earth wall [7]

\section{EARTHEN BUILDINGS IN ROMANIA}

In 16th century Romania, during construction of Orthodox churches, the techniques used were cobweb or cob (ceamur) with wooden elements and covered with reeds. Some examples include the old churches from Oltina, Beidaud or Istria, in the Dobrogea region.

In the documentary attestations The old church in Oltina was built in. It has a small height of $3.5 \mathrm{~m}$ and the absence of the tower indicate that the church was built at the time when Dobrogea was a Turkish territory. During that period Christian churches were not allowed to be taller than a mosque. The construction type is semi-buried like many other churches built in that period, and the technique used is cobweb (a wooden structure woven from twigs and earth). The functionality is the same as any Christian church: porch, narthex, nave and altar. The church has no foundation, the whole building is resting on wooden pillars, buried one meter underground. As a construction technology, it can be noticed that the entire wooden work was made only with the use of axe and chisel, with wooden nails used for joining.

The church in Satu Nou, Constanța County, was built in 1861 by a Turkish craftsman, or according to other information was built by the village community, on land donated by 


\section{sciendo}

Ovidius University Annals Series: Civil Engineering, Year 23, 2021105

Raşit, who owned the village and the surrounding lands, and who would have borne the cost of the roof pantiles.

The walls of the church were built of twigs, lumped with earth and straw, lined with planks on the outside, like the two other churches in the area, all included in the list of historical monuments. Inside, the narthex is separated from the nave by a slatted wall, reminiscent of the interior of a mosque. The church is sheltered under a short roof, unique for the whole building, covered with pantiles. The narthex has a ceiling.

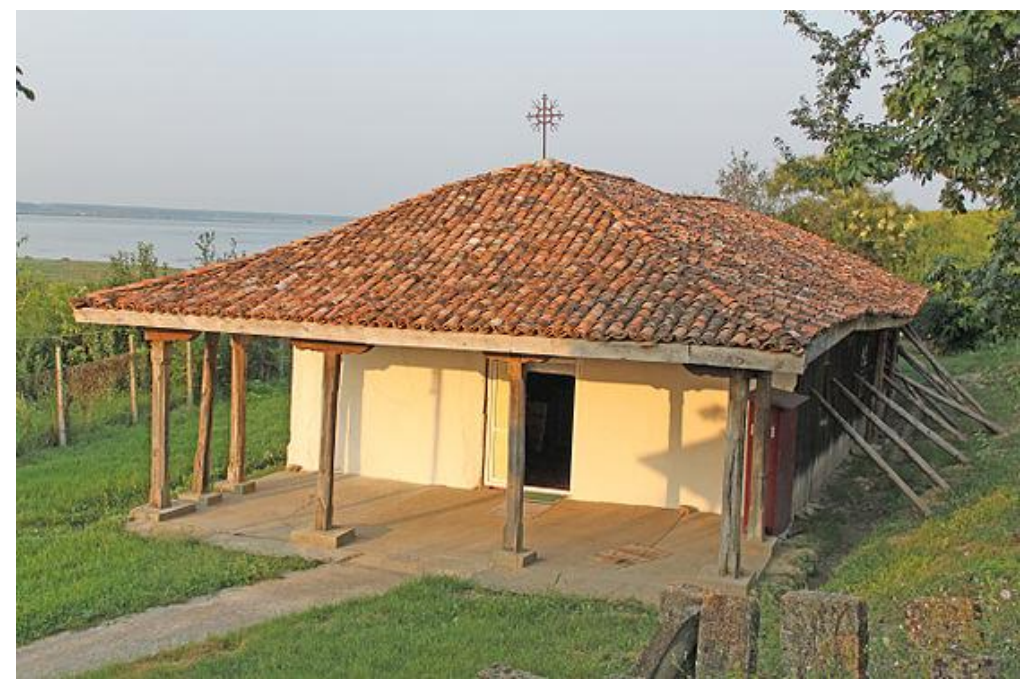

Fig. 10. Church in Satu Nou, Constanta County [8]

Wooden churches are among the few that are still preserved in Europe and therefore have a unique value for national and European heritage.

The last hut type churches disappeared from the south of the country in the early 20th century before anyone had the chance to document them. These kinds of churches had unique archaic features that would have given them an exceptional value.

\section{CONCLUSIONS}

The tradition of building with earth is deeply rooted in the collective wisdom of the human race. However, along with the industrial revolution, the discovery of new and improved building materials made people mistrust this material. Earth constructions have become a symbol of poverty and are not associated with endurance. The advantages of using earth for construction, as well as recent discoveries in this field, regarding execution technologies and protection of earth made elements have yielded a new interest in this material. There is an urgent need for further research in this field which should aid in developing design codes that can be used to benefit from this natural and abundant material.

\section{REFERENCES}

[1] Minke G. (2008), Construind cu pamant - proiectare si tehnologii pentru o arhitectura durabila, Simetria

[2] OAR, Ghid de arhitectura pentru incadrarea in specificul zonei din mediul rural 


\section{sciendo}

106 Ovidius University Annals Series: Civil Engineering, Year 23, 2021

[3] A. M. Daniela Barbu, Alexandru Ioniță, Ana Maria Grămescu, Criteria and procedures of analisis applicabile in the evaluation of the archaeological heritage, International Scientific Conference CIBv 2019 - http://iopscience.iop.org/journal/1757-899X în curs de publicare

[4]Ana Maria Grămescu, The history of the science and technique of constructions expression of the Turkish civilization in the Dobrogea area, presentation of the Scientific Symposium May 19, 2019 in CRIFST Constanța. The history and philosophy of science and technology - Romanian Academy

[5]Ana Maria Grămescu, Mihaela Pericleanu, Sever Suliman, History of Science and Tehnique of Buildings- Expression of a Turkish-Tatar Civilization in Dobrogea, pag 263278 publicat în volumul Dobrogea at 140 yars after its Union with the Romanian State - An Exemple of Contemporary West-Pontic Multiethnic Understanding, EX PONTO 2018 ISBN 978-606-598-700-5, Editor Bologa Alexandru

[6] wikipedia.org

[7] enablerllc.com

[8] wikiwand.com

\section{Note:}

Tudorel Seitan - PhD, Ovidius University of Constanta, Institute of Doctoral Studies, Bd. Mamaia nr. 124 900356-Constanta, Romania (corresponding author to provide e-mail: seitandoru@ gmail.com)

Ana Maria Gramescu - Ovidius University of Constanta, Institute of Doctoral Studies, Bd. Mamaia nr. 124, 900356-Constanta, Romania (e-mail: am gramescu@yahoo.com) 